U.S. Department of Agriculture

Animal \& Plant Health Inspection Service

Wild life Services

August 2017

Wildlife Damage Management Technical Series

\title{
Herons and Egrets
}

Michael D. Hoy

District Supervisor

USDA-APHIS-Wildlife Services

Almyra, Arkansas

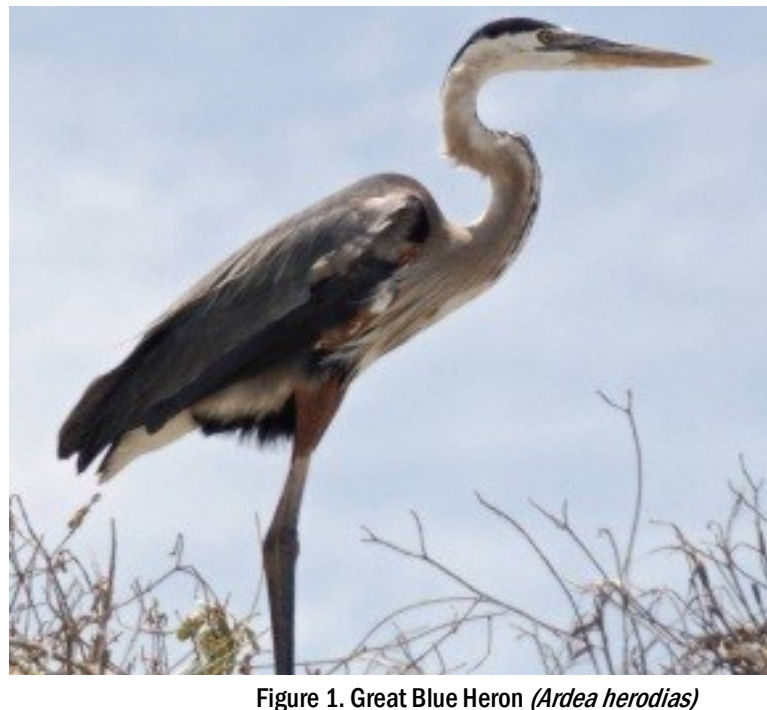

\section{Human-Wildlife Conflicts}

\section{Landscapes}

Herons and egrets commonly cause damage at aquaculture facilities and recreational fishing waters where fish are held at high densities. In one study, on average wading birds consumed from 4 to 24 golden shiners per day at minnow production facilities in Arkansas. Great blue herons and great egrets commonly feed at catfish production facilities in Mississippi. The tendency for herons and egrets to congregate in large feeding flocks often leads to extensive loss of fish at aquaculture facilities.
Fish-eating birds also can have an impact on intensively managed sport fisheries. Damage occurs when herons and egrets feed on fish purchased and released for recreational sport fishing activities. Values of these fish can be quite high given the intensity of management activities and the direct relationship of fishery quality to property value.

\section{Livestock and Pets}

Great blue herons are known to feed on fish in backyard water gardens. This can be a problem in urban areas as fish in these small ponds often are considered valuable pets. 


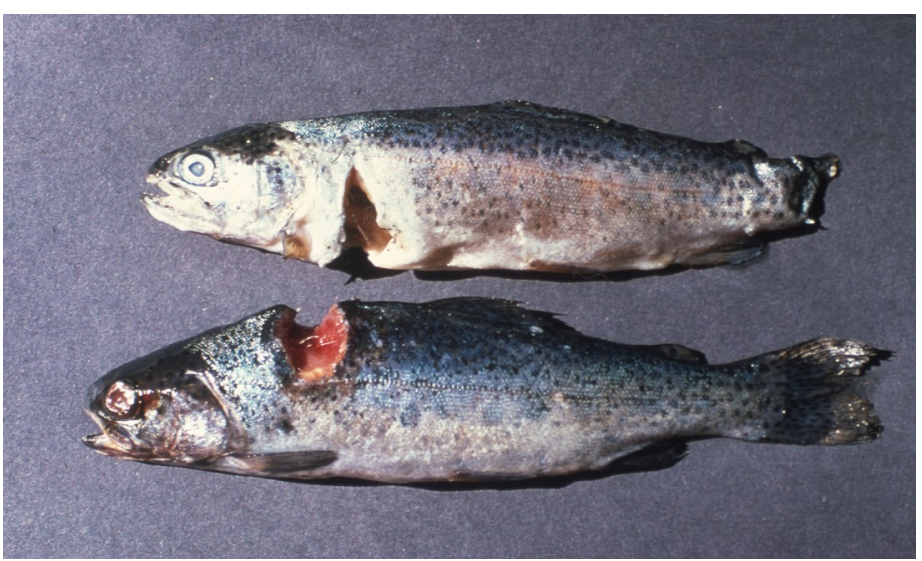

Figure 2. Great blue heron damage to fish.

\section{Human Health and Safety}

Nesting colonies often cause problems in urban areas when urbanization spreads into lowland habitats where colonial nest sites have traditionally existed. Odor from deposited fecal material in these areas is a problem. Histoplasmosis is not commonly found in soils from heron/ egret rookeries, but proper conditions for this fungal disease exist in these areas. Rookeries near airports may pose a flight safety risk to aircraft.

\section{Damage Identification}

Often, heron and egret damage initially is identified by the presence of birds feeding at the damage site. Further investigation will determine that fish are missing or damaged (Figure 2). Damage often includes puncture holes or slices on the back or sides of a fish.

Occasionally, damage at aquaculture facilities is not realized until harvest when fish production falls short of expectations. This is often the case if ponds are not regularly frequented by humans or if birds are feeding at night.

\section{Management Methods}

Integration of multiple control methods is essential in developing a strategy to manage heron and egret damage. If implemented in a timely and persistent manner, all methods discussed below will provide effective control of wading bird damage. Reliance on one method rarely works to prevent or control extensive bird damage. When developing a control program, realize that every damage situation is unique. Incorporate the uniqueness of the situation into your control program and use as many control strategies as possible to develop your management strategy.

\section{Habitat Modification}

Small, shallow impoundments are attractive feeding sites for wading birds and should be avoided. Herons and egrets will rapidly congregate if fish are left in these conditions for extended periods. Shallow water conditions are often necessary to harvest commercial fish and cannot be avoided. If this occurs, be prepared to implement frightening devices to disperse the birds.

Diseased fish are highly vulnerable to heron and egret depredation. Maintain quality fish health standards to help minimize wading bird depredation.

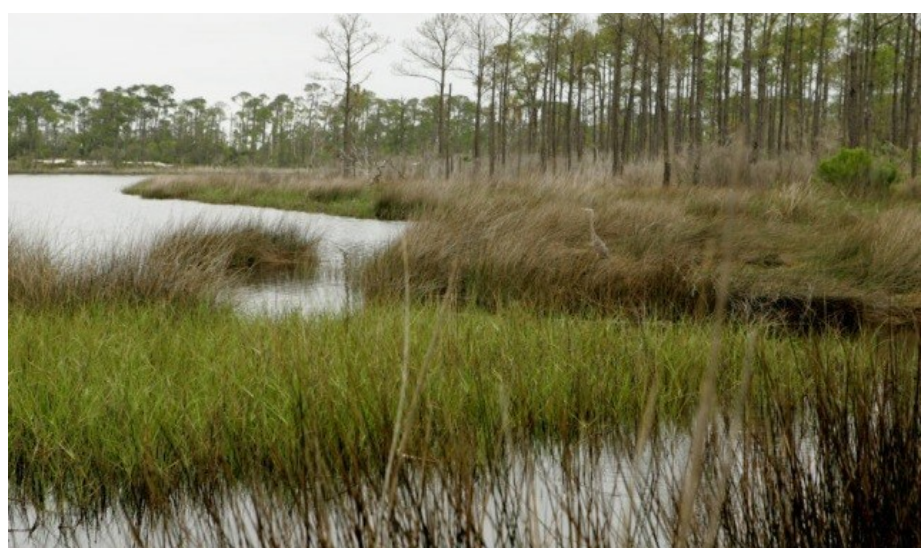

Figure 3. Herons and egrets prefer vegetated banks. 
Herons and egrets prefer to feed along vegetated banks where they are concealed from their prey (Figure 3). Pond banks without vegetation are less attractive to birds and will decrease the efficiency of wading bird feeding.

Urban rookeries can be prevented by adequately thinning nesting habitat. Since herons and egrets are protected under the Migratory Bird Treaty Act, habitat management in active rookeries is prohibited. All habitat modifications to prevent future rookeries must be performed during the nonbreeding season. In some situations, it is possible to get a Migratory Bird Depredation Permit from the U.S. Fish and Wildlife Service (USFWS) to allow habitat modifications during the breeding season. Contact your local USFWS office for further guidance.

\section{Exclusion}

Total exclusion is the complete enclosure of an area with netting or wire mesh caging to eliminate bird use (Figure 4). Exclosures are the only way to completely restrict heron and egret access to ponds and raceways. It is effective, but due to cost and structural problems in spanning large distances, it is generally considered impractical to totally exclude birds at water holding structures larger than 5 acres. In addition, exclosures are difficult to incorporate into a commercial aquaculture facility as they can interfere with fish management practices.

Total exclosures are recommended for protection of fish in urban water gardens. The small ponds and high value fish make this control method cost effective. However, the exclusion system may be aesthetically unacceptable to the landowner.

Partial exclusion is the limited enclosure of an area with wire or string lines to discourage bird use (Figure 4). The lines are run laterally or set in a grid pattern across ponds or raceways to impede access by birds. Partial exclusion is usually less expensive than total exclosure, but will not eliminate heron and egret use of the site. As with total exclusion, overhead wire systems are impractical for large ponds due to the difficulty in spanning large distances.

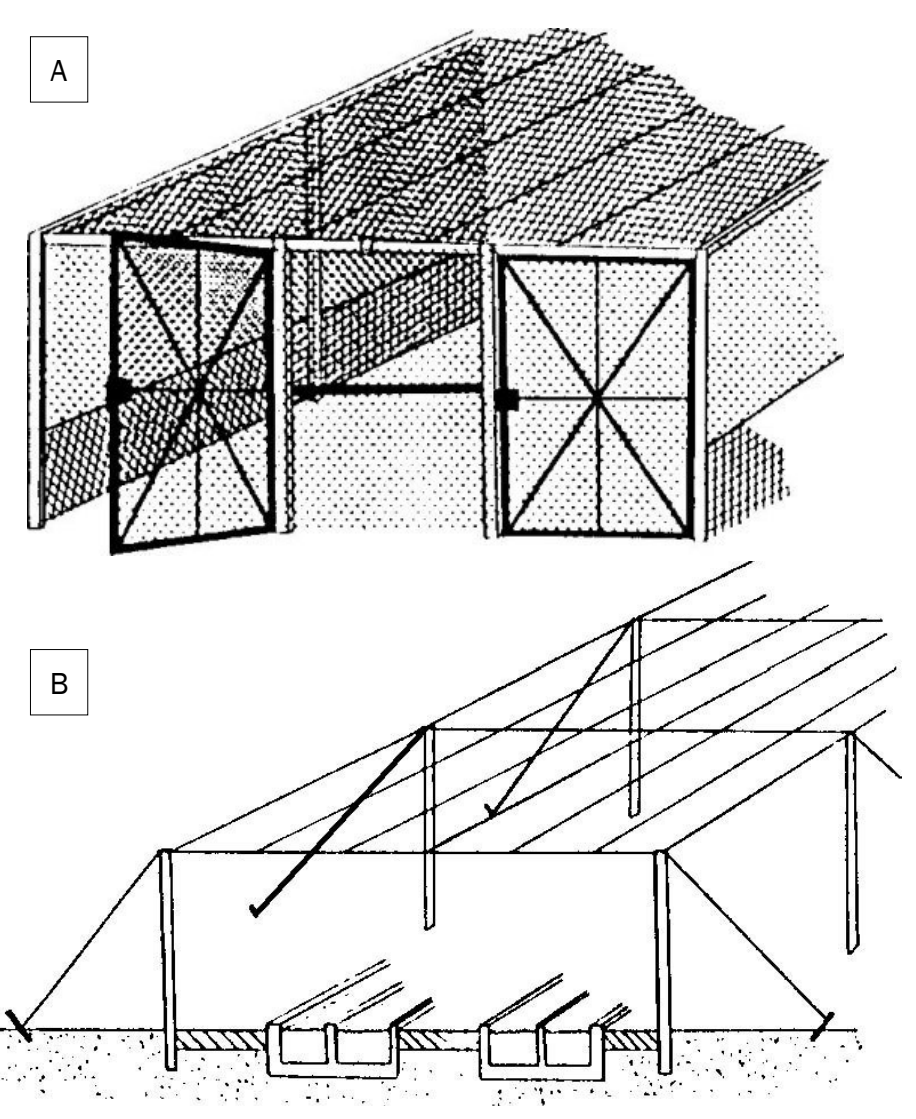

Figure 4. A total exclosure eliminates access by birds completely (a), whereas overhead lines or wires provide only partial exclusion (b).

Overhead wire exclosures are easier to incorporate with fish management practices and are easier to maintain than complete enclosures. Overhead wire systems are considered cost effective for small ponds (less than 5 acres). It is recommended that high-value fish subject to predation by herons and egrets be raised in small ponds with overhead wire systems.

All exclusion systems must be structurally sufficient to withstand the weight and impact of birds. Consider weather conditions; the infrastructure should be strong enough to support accumulations of ice and snow. 
Perimeter fencing and wires have been used with limited success to exclude herons and egrets from ponds. Wading birds quickly acclimate to barriers and jump over wires to feed on fish. Electric perimeter wires also have proven to be ineffective and impractical for most situations.

\section{Frightening Devices}

Frightening devices are effective tools for dispersing large concentrations of herons and egrets from damage sites. Many visual and noise-making devices are commercially available for scaring birds, including gas-operated exploders, pyrotechnics, electronic noise makers, bird distress calls, effigies, eyespot balloons (Figure 5), reflective tape, and water spray devices. Methods for incorporating these devices into a bird scaring program are described in the Bird Dispersal Techniques publication of the Wildlife Damage Management Technical Series. As discussed previously, it is important to use a variety of frightening devices in a timely and persistent manner.

At large aquaculture facilities, the effectiveness of these devices is compromised over time as herons and egrets become habituated to the deterrents. At this point, frightening devices will simply push herons and egrets from one pond to another nearby pond where they will continue feeding. Lethal control may be necessary to enhance the overall effectiveness of a bird scaring program at these sites. See the Shooting section for more details.

At urban rookeries, frightening devices can be used to relocate birds prior to nesting. Once active nests are established, it is illegal to intentionally disperse birds from a nest site. Contact the USFWS for further clarification.

\section{Repellents}

None are registered.

\section{Fertility Control}

None are available.

\section{Toxicants}

None are registered.

\section{Trapping}

Allowed with permits, but typically ineffective at controlling damage.

\section{Shooting}

It is illegal to shoot herons and egrets without a permit from the USFWS. A permit can be obtained by commercial fish farms to augment their on-going nonlethal harassment programs. Contact USDA APHIS Wildlife Services or your state wildlife agency for more information.

\section{Economics}

Heron and egret damage is difficult to quantify. The relative abundance of fish among aquaculture ponds is highly variable. Therefore, it is difficult to assess the overall impact of bird depredation until harvest.

Loss estimation requires knowledge of the number of birds present, feeding duration, number of fish taken, and the crop value. One study assessed esophageal and stomach contents of 4 species of herons in Arkansas and found losses of golden shiners ranged from $\$ 0.10$ to $\$ 0.62$ per feeding. Based on 2 feedings per day, a flock of 100 wading birds present on a fish farm for a 3-month period

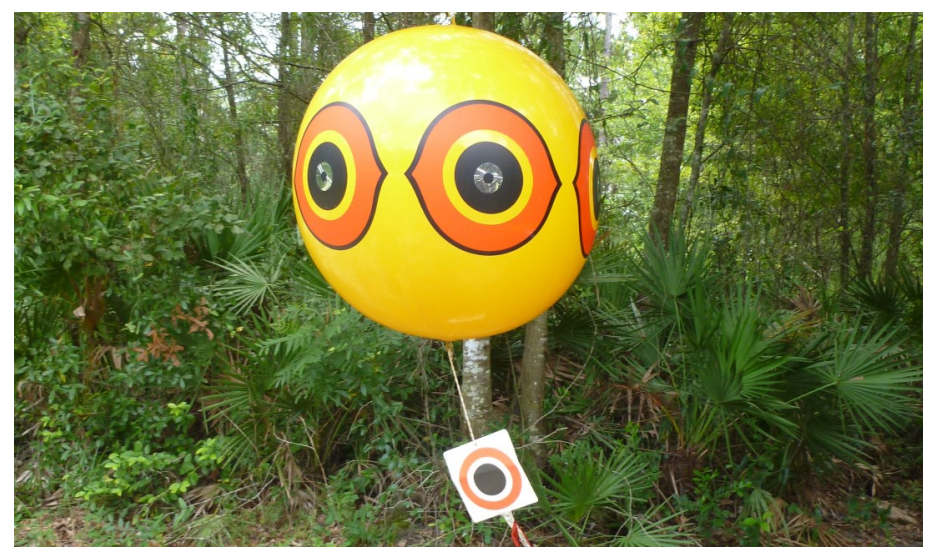

Figure 5. "Eye-spot" balloons may help protect small areas from heron and egret damage for a limited period of time. 
resulted in losses from $\$ 1,800$ to $\$ 11,160$, depending on the species composition.

Indirect economic impact can occur when herons carry unwanted fish and vegetation into the aquaculture facility. Cross contamination of fish from nearby ponds can lead to unwanted polyculture and decreased crop values. Birds also have been implicated in the spread of fish diseases between pond complexes.

\section{Species Overview}

\section{Identification}

Herons and egrets are freshwater or coastal birds of the family Ardeidae. The most common species include:

- Great blue heron (Ardea herodias)

- Great egret (Casmerodius albus)

- Snowy egret (Egretta thula)

- Little blue heron (Egretta caerulea)

- Cattle egret (Bubulcus ibis)

- Green heron (Butorides virescens)

- Black-crowned night-heron (Nycticorax nycticorax)

- Yellow-crowned night-heron (Nycticorax violaceus)

\section{Physical Description}

Herons and egrets are medium to large sized birds with characteristic long legs, necks, and pointed bills. Legs are extended and heads retracted during flight. They are sexually monomorphic and typically colonial nesters. The great blue heron (Figure 1) is approximately 4 feet tall with blue-grey plumage and weighs between 5 and 6 pounds.

Great egrets (Figure 6) are slightly smaller than great blue herons and are white with black legs.

Snowy egrets (Figure 7 ) are approximately 27 inches tall and are white with black bills and legs and characteristic yellow feet.

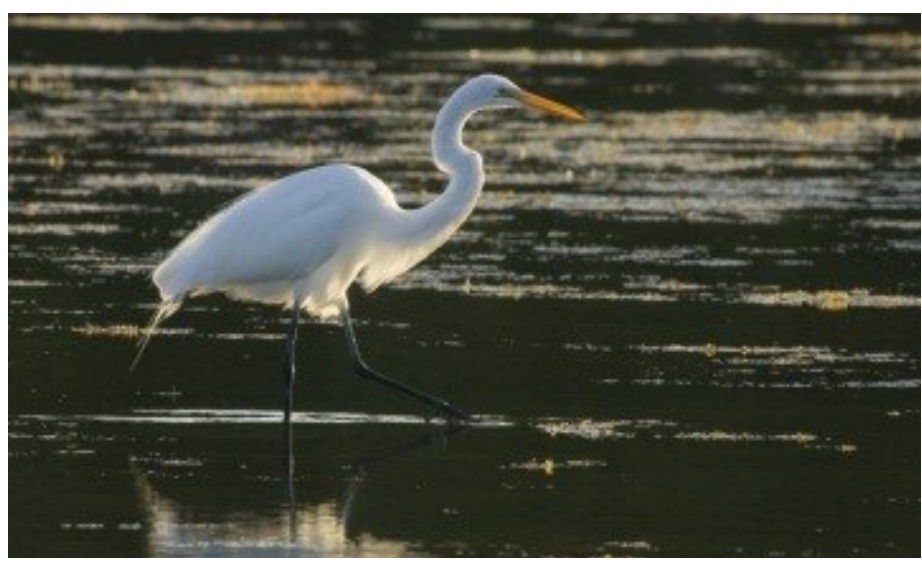

Figure 6. Great egret walking through water.

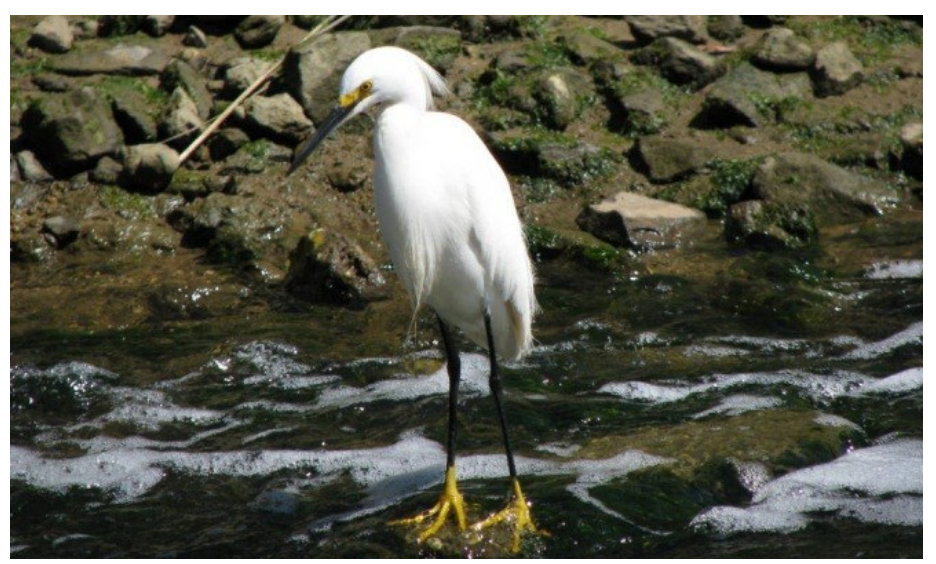

Figure 7. Snowy egret with characteristic yellow feet.

Little blue herons (Figure 8) are similar in size to snowy egrets, but blue grey with a maroon neck. Immature little blue herons are dusky white with dull green legs.

Cattle egrets (Figure 9) are slightly smaller than snowy egrets and are white with yellow bills and dark yellow or coral legs.

Green-backed herons (Figure 10) are approximately 28 inches tall, with a blue-green back and chestnut neck.

Night-herons are similar in size to snowy egrets but grey, short-legged and thick-billed. Black-crowned night-herons have a black back and neck (Figure 11).

Yellow-crowned night-herons (Figure 12) are similar to black-crowned, but have a white cap and cheek patch. 


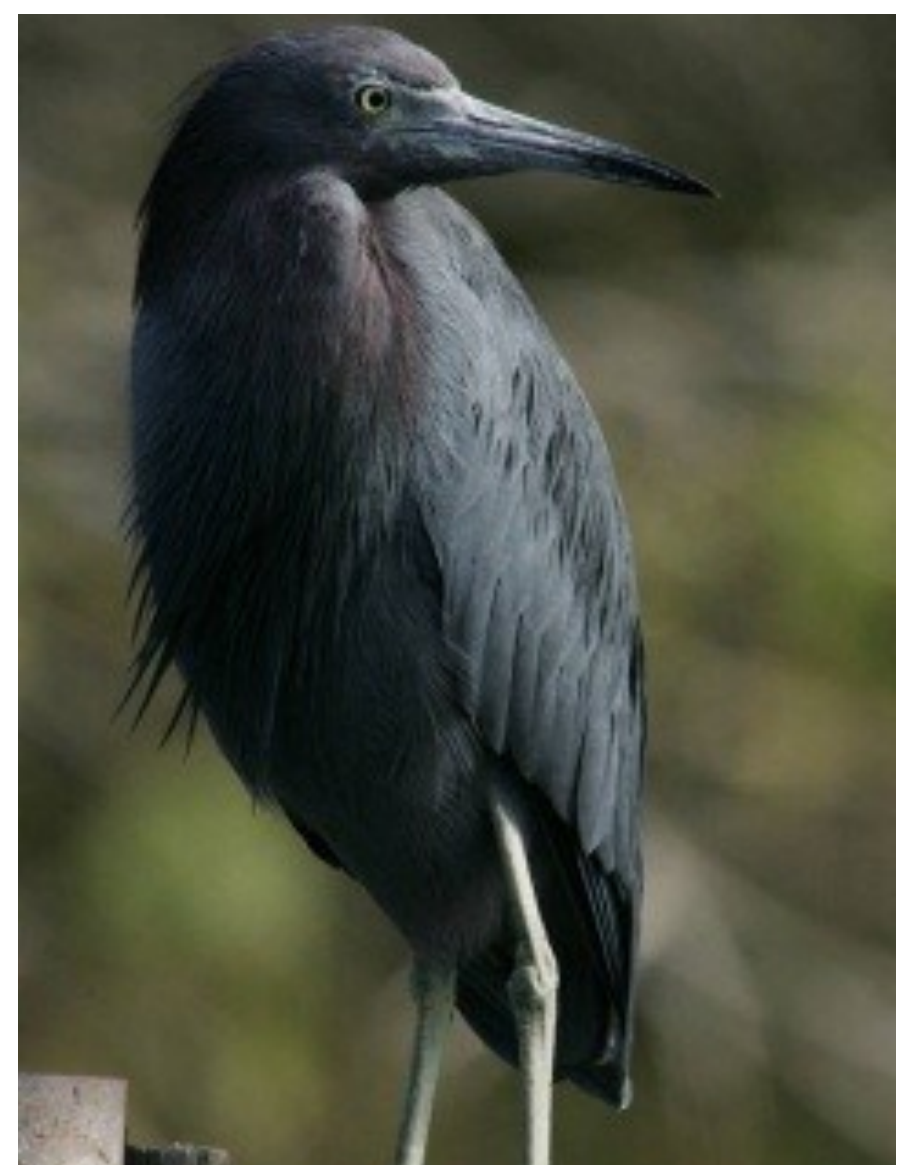

Figure 8. Little blue heron.

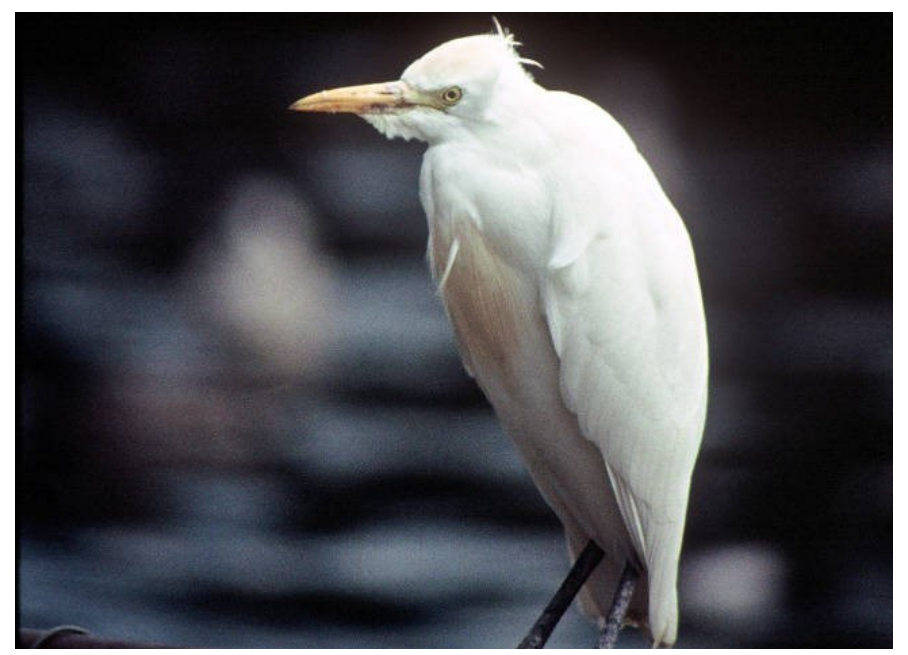

Figure 9. Cattle egret.

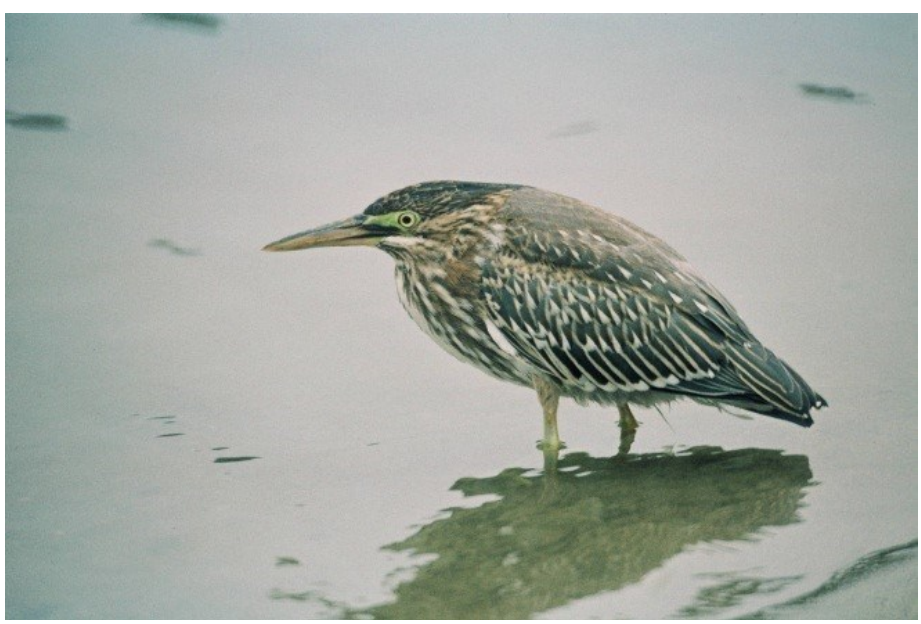

Figure 10. Green-backed heron.

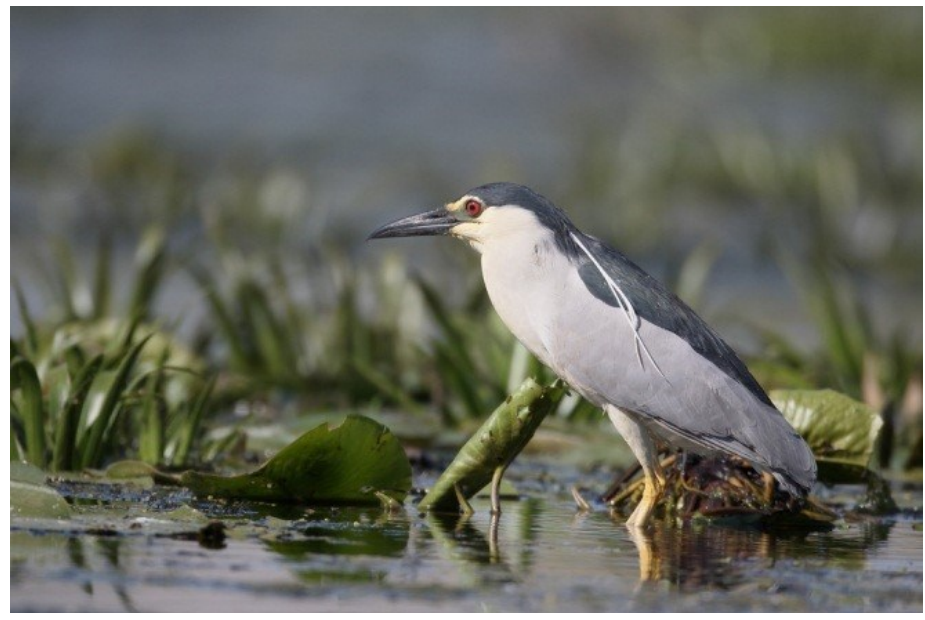

Figure 11. Black-crowned night heron in water.

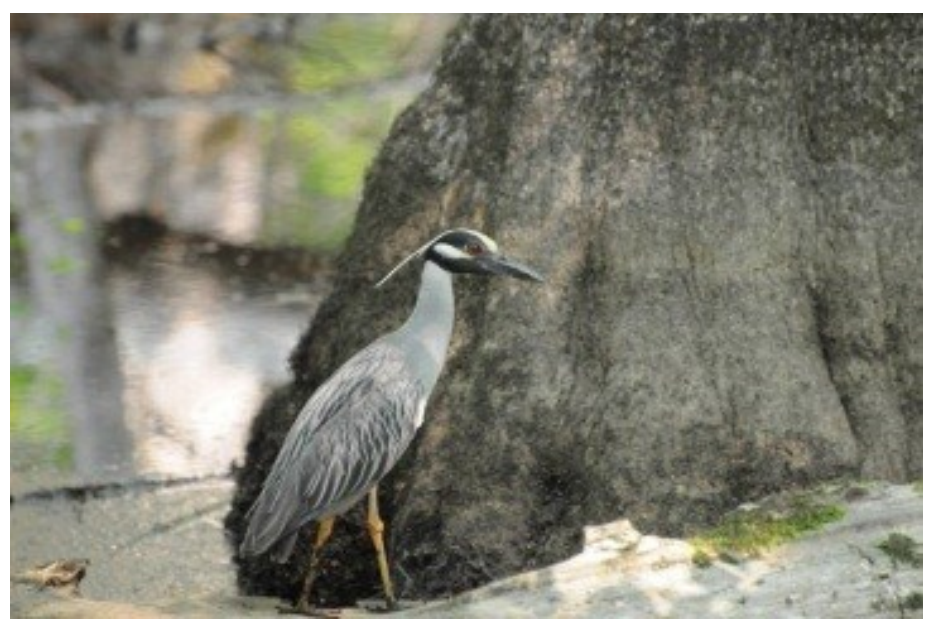

Figure 12. Yellow-crowned night heron showing white cheek patch and cap. 


\section{Range}

The great blue heron can be found in wetland areas across most of the U.S. and lower Canada (Figure 13). The great egret occurs along coastal U.S. with many wintering areas in South and Central America (Figure 14). The cattle egret appeared in North America in the 1950s; by the 1990s, it had become common in many regions. For range information on other species, please see The Birds of North America Online.

\section{Tracks and Sign}

Herons and egrets are most frequently identified by sightings near water or concentrations at communal

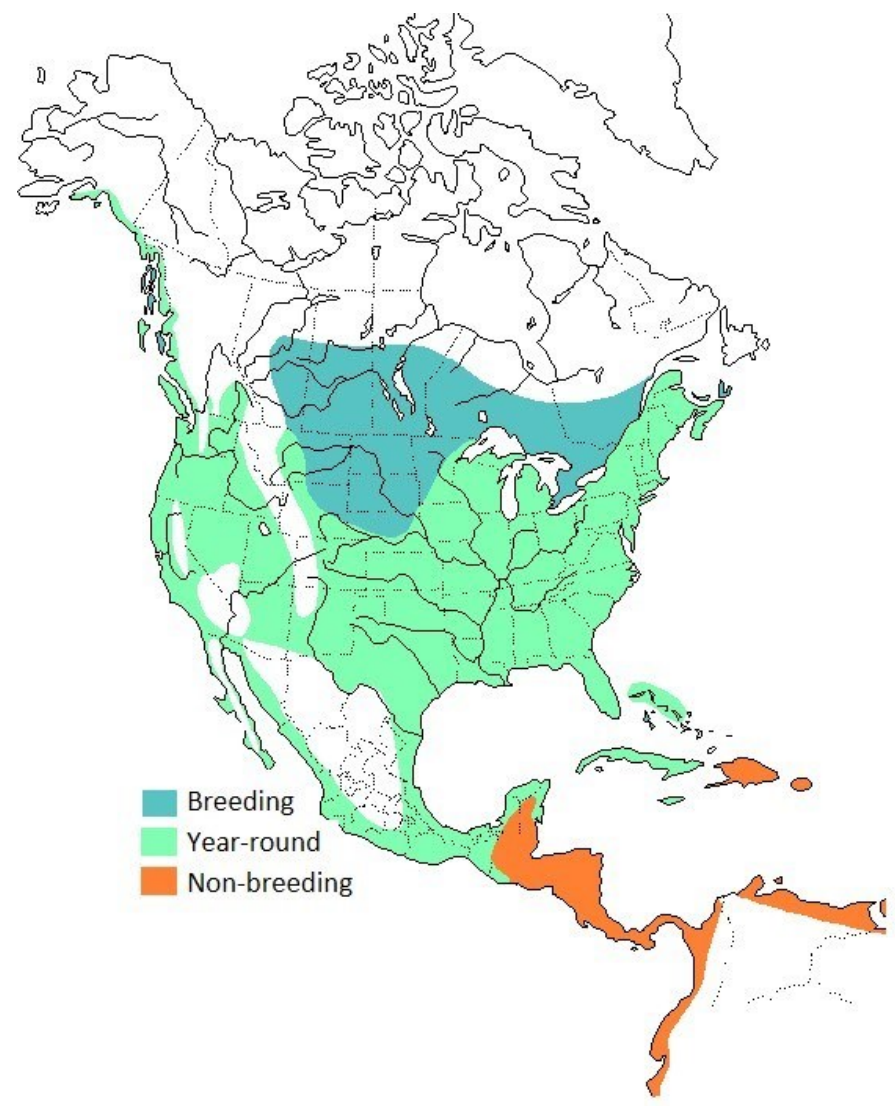

Figure 13. Breeding, non-breeding, and year-round ranges of the great blue heron. roosts. For sign associated with aquaculture damage, see section on Damage Identification.

\section{Voice and Sounds}

Herons and egrets have distinctive vocalizations, but these generally are not beneficial for identification. The most common sounds associated with great blue herons are squeaking roh-roh-rohs when landing or a series of clucking go-go-gos building to a rapid frawnk squawk. Great egrets make dry, croaking sounds, nasal squeals and other harsh calls. For vocalizations of other species, please see The Birds of North America Online.

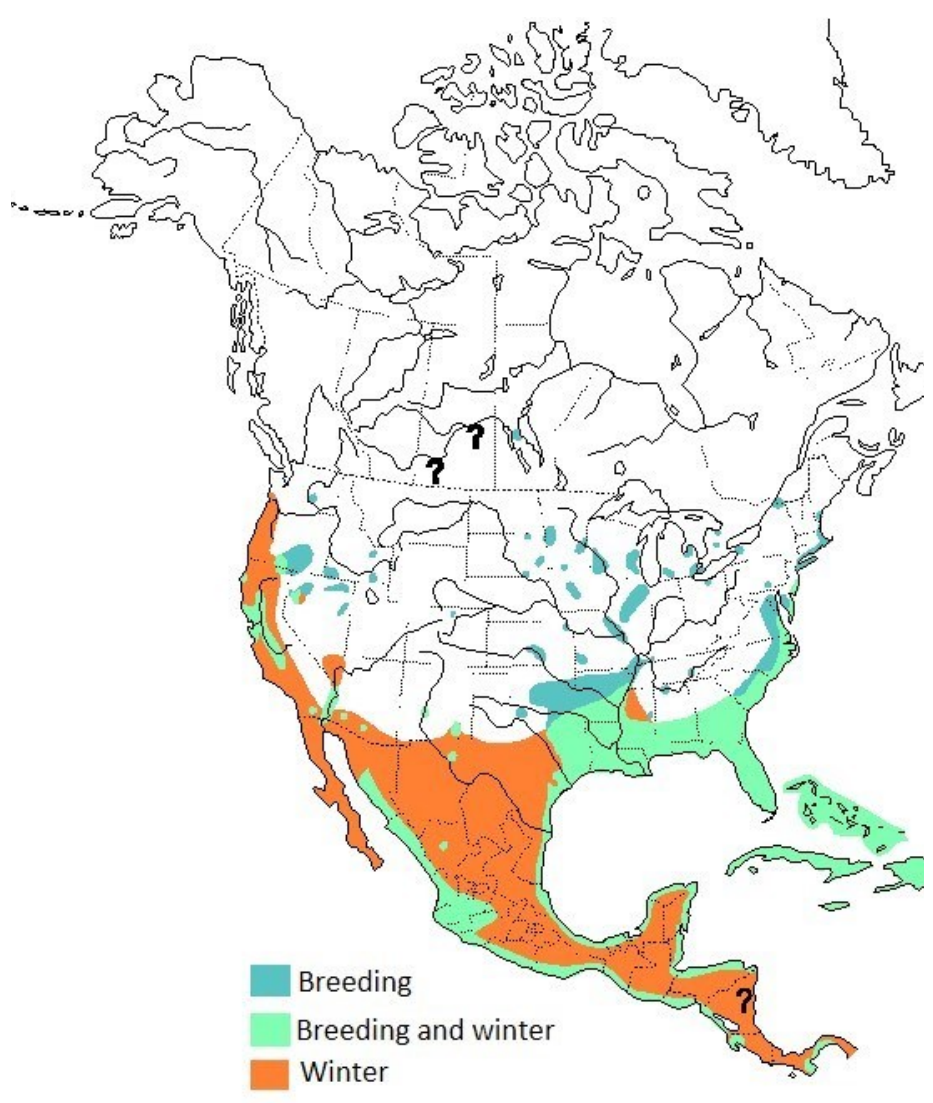

Figure 14. Distribution of great egret. 


\section{Reproduction}

The size of the clutch, length of incubation, and age at which birds reach sexual maturity varies by species. Great blue herons breed from March to May in the northern part of their range. Females lay 3 to 6 eggs after mating. Those living farther north have the higher clutch sizes. Both sexes incubate the eggs, which hatch after 26 to 30 days.

Parents feed the young by regurgitating food the nest. The young fledge about 2 months after hatching and are sexually mature at about 22 months. Great egret females lay 3 to 4 eggs after mating. Both sexes incubate the eggs, which hatch in about 24 days. The young fledge about 2 to 3 weeks after hatching and can reproduce after 2 years. For information on other species, please see The Birds of North America Online.

\section{Mortality}

Great blue herons commonly live more than 15 years and occasionally 24 years or more in the wild. More than half of the great blue herons born in any given year die before they are a year old. Great egrets have similar lifespans and mortality rates. For information on other species, please see The Birds of North America Online.

\section{Population Status}

The great blue heron and great egret suffered from heavy hunting pressure in the late 1800 s and early 1900 s for their breeding plumes. That, along with habitat loss due to drainage of wetlands, had a negative impact on their populations. According to the North American Breeding Bird Survey, populations of great egrets increased significantly from 1966 to 2010 in the U.S. The little blue heron, cattle egret, and green heron showed declines in population over the same years. For information on other species, please see The Birds of North America Online.

\section{Habitat}

Varies by species, but all are associated with wetlands throughout their life history. According to the Birds of North America online, the cattle egret's preference for "lawns, fields, pastures and grazing animals is quite unlike other native North American herons and egrets, which generally feed in or along water and not in close association with livestock."

\section{Behavior}

Foraging habits vary by species, but herons and egrets typically wade in shallow water in pursuit of prey. Feeding by hovering and diving by these species has been observed when fish are concentrated in deep, open water. Great blue herons are known to herd minnows toward shallows of aquaculture ponds to increase foraging efficiency.

Herons and egrets are diurnal sight feeders that return to roost at dusk. They will feed at night with favorable moonlight or when disturbed from feeding during the day. Night-herons are the exception, as they prefer to feed at night and roost during the day.

Herons and egrets are known to congregate in large flocks when fish are concentrated in shallow water.

Species in the Family Ardeidae are typically colonial nesters. Their rookeries are often found in densely vegetated, lowland habitats or wetland areas.

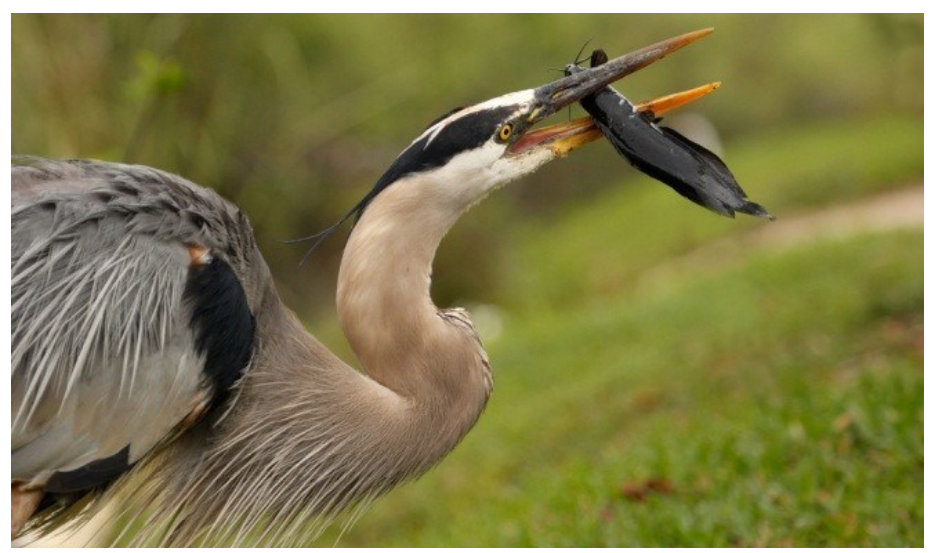

Figure 15. Great blue heron eating a fish. 


\section{Food Habits}

Herons and egrets discussed in this section are all piscivorous (Figure 15). They are opportunistic feeders, however, and will consume small amphibians, insects, and reptiles. Due to these food preferences, herons and egrets are attracted to shallow lakes and human-made impoundments.

\section{Legal Status}

Native bird species are covered under the Migratory Bird Treaty Act (MBTA) and given federal protection.

Depredation permits can be obtained through the U.S. Fish and Wildlife Service. In addition, individual states may require their own permits for legal take of these bird species. 


\section{Acknowledgements}

Figure 1. Photo by Robert Burton, USFWS

Figure 2. Photo by USDA

Figure 3, 6 and 8. Photos by Steve Hillebrand, USFWS

Figure 4. Images from 1994 Prevention and Control of Wildlife Damage

Figure 5. Photo by John Humphreys, USDA-APHIS-WS

Figure 7. Photo by Jama Beasley, USFWS

Figure 9 and 10. Photos by Lee Karney, USFWS

Figure 11. Photo by Erni, Shutterstock.com

Figure 12. Photo by Mark Musselman, National Audubon Society and USFWS

Figures 13 and 14. Maps from The Birds of North America Online (A. Poole, Ed.). Ithaca: Cornell Lab of Ornithology.

Figure 15. Photo by Don Mammoser, Shutterstock.com

Portions of Prevention and Control of Wildlife Damage, 1994, Bird Damage at Aquaculture Facilities by W. Paul Gorenzal, Fred S. Conte, and Terrell P. Salmon were used in development of this publication. Special thanks to Thurman Booth, Brian Dorr, Harris Glass, Kris Godwin and Michael Kearby for their critical review.

\section{Glossary}

Piscivore: An animal that feeds on fish.

Polyculture: The simultaneous cultivation of several crops or kinds of animals.

Rookery: A colony of breeding birds; the nesting place of birds. For herons, it may be called a heronry.

Sexual Monomorphism: The males and females of a species show no differences in coloration, size or body structure other than their genitalia.

\section{Key Words}

Aquaculture, Ardea herodias, Casmerodius albus, Egret, Fish predation, Heron

\section{Disclaimer}

Wildlife can threaten the health and safety of you and others in the area. Use of damage prevention and control methods also may pose risks to humans, pets, livestock, other non-target animals, and the environment. Be aware of the risks and take steps to reduce or eliminate those risks.

Some methods mentioned in this document may not be legal, permitted, or appropriate in your area. Read and follow all pesticide label recommendations and local requirements. Check with personnel from your state wildife agency and local officials to determine if methods are acceptable and allowed.

Mention of any products, trademarks, or brand names does not constitute endorsement, nor does omission constitute criticism.

\section{Citation}

Hoy, M.D. 2017. Herons and Egrets. Wildlife Damage Management Technical Series. USDA, APHIS, WS National Wildlife Research Center. Fort Collins, Colorado. 12p. 


\section{Resources}

Glahn, J.F., D.S. Reinhold, and P. Smith. 1999. Wading bird depredations on channel catfish (Ictalurus punctatus) in northwest Mississippi. J. World Aquaculture Soc. 30:107-114.

Hoy, M.D., J.W. Jones, and A.E. Bivings. 1989. Economic impact and control of wading birds at Arkansas minnow ponds. Eastern Wildl. Damage Control Conf. 4:109-112.

Hoy, M.D. 1994. Depredations by herons and egrets at bait fish farms in Arkansas. Aquaculture 20:52-56.

Krebs, J.R., and B. Partridge. 1973. Significance of head tilting in the great blue heron. Nature 242:533-535.

Kushlan, J.A. 1976. Wading bird predation in a seasonally fluctuating pond. Au. 93:464-476.

Kushlan, J.A. 1978. Feeding ecology of wading birds. Pages 249-297 in A. Sprunt, J.C. Ogden, and S. Winckler, eds. Wading birds. Rep. No.7. Natl. Audubon Soc., New York.

McCrimmon, Jr., Donald A., John C. Ogden and G. Thomas Bancroft. 2011. Great Egret (Ardea alba), The Birds of North America Online (A. Poole, Ed.). Ithaca: Cornell Lab of Ornithology; accessed Sept. 17, 2015 from the Birds of North America Online at: http://bna.birds.cornell.edu/bna/species/570

Telfair II, Raymond C. 2006. Cattle Egret (Bubulcus ibis), The Birds of North America Online (A. Poole, Ed.). Ithaca: Cornell Lab of Ornithology; accessed Sept. 17, 2015 from the Birds of North America Online at http://bna.birds.cornell.edu/ $\underline{\text { bna/species } / 113}$

Vennesland, Ross G. and Robert W. Butler. 2011. Great Blue Heron (Ardea herodias), The Birds of North America Online (A. Poole, Ed.). Ithaca: Cornell Lab of Ornithology; accessed Sept. 17, 2015 from the Birds of North America Online at http://bna.birds.cornell.edu/bna/species/025

Internet Center for Wildlife Damage Management (http://icwdm.org)

National Wildlife Control Training Program (http://wildlifecontroltraining.com)

The Birds of North America Online (A. Poole, Ed.). Ithaca: Cornell Lab of Ornithology 


\section{Appendix}

Damage Management Methods for Herons and Egrets

\begin{tabular}{l|l}
\hline Type of Control & Available Management Options \\
\hline
\end{tabular}

Exclusion

- Total exclosures are recommended for protection of fish in urban water gardens.

- $\quad$ Overhead wires are more practical for larger areas.

Fertility Control None available.

Frightening Devices - Propane cannons, pyrotechnics, and other noise making devices.

- Various visual devices effective on small ponds including flash tape, mylar balloons, scarecrows and effigies.

- $\quad$ Distress calls generally ineffective.

Habitat Modification - Maintain water depth, promote steep pond banks, and eliminate vegetation at waterline at aquaculture facilities.

- Thin vegetation at roost sites.

Repellents None registered.

Shooting Allowed with proper Federal and State permits.

Toxicants None registered.

Trapping Allowed with proper permits, but generally not effective for controlling damage. 